\title{
Compatibility of Different Systemic and Non Systemic Fungicides with Trichoderma viride
}

\author{
Shashank Mishra ${ }^{1}{ }^{*}$, Prashant Mishra $^{1}$, Ramji Singh $^{1}$, Gopal Singh ${ }^{1}$ and S.K. Sachan ${ }^{2}$ \\ ${ }^{1}$ Department of Plant Pathology, ${ }^{2}$ Department of Entomology, SVPUA\&T, Meerut- 250110, \\ Uttar Pradesh, India \\ *Corresponding author
}

\section{A B S T R A C T}

\begin{tabular}{|l|}
\hline K e y w o r d s \\
Different systemic, \\
Non systemic, \\
Fungicides \\
Trichoderma viride \\
\hline Article Info \\
\hline $\begin{array}{l}\text { Accepted: } \\
\text { 10 December } 2018 \\
\text { Available Online: } \\
\text { 10 January } 2019\end{array}$ \\
\hline
\end{tabular}

Biological control involves the use of antagonistic microorganisms to attack and control plant pathogens, diseases and the disease producing activities they cause. It is an environmentally acceptable and ecologically viable approach which is compatible with different models of disease management i.e., organic, biological and integrated disease management (IDM) programmes. The chief antagonist used for disease management in Agriculture is the fungus Trichoderma viride, an effective and low cost biocontrol agent that can establish itself in different pathosystems. Nine fungicides namely Azoxystrobin, Iprodione, Tebuconazole, Hexaconazole, Propiconazole, Carbendazim and Thiopanate Methyl at 25, 50, $100 \mathrm{ppm}$ and two fungicides viz., Captan and Mancozeb at 50, 100, 200ppm concentration were evaluated for their compatibility with the bioagent Trichoderma viride using poisoned food technique. The data showed that all fungicides significantly reduced the radial growth of Trichoderma viride. Mancozeb showed least inhibition (42.96\%) at $200 \mathrm{ppm}$ and compatible with Trichoderma viride. In case of five other fungicides Azoxystrobin, Tebuconazole, Hexaconazole, Propiconazole and Carbendazim completely inhibited the growth and not compatible with Trichoderma viride, while Thiopanate Methyl, Iprodione and Captan exhibited intermediate inhibitory effect and less compatible with Trichoderma viride.

\section{Introduction}

Sclerotinia sclerotiorum (Lib.) de Bary is a cosmopolitan necrotrophic fungal plant pathogen with a wide host range, including over 400 different plant species (Boland and Hall, 1994; Purdy, 1979). Increase in host range of S. sclerotiorum narrows down the opportunity for disease management using either crop rotation or resistant varieties. This pathogen is the causal agent of sclerotinia stem rot in lentil, leading to serious losses in yield due to lodging and premature shattering of seedpods (Gugel and Morrall, 1986). The stem rot fungus overwinters as sclerotia in the soil, in stubble at the soil surface and mixed with seed. Sclerotia can remain viable in the field for five years or more. Each year some sclerotia will germinate when conditions are suitable but others will remain dormant. Germination is either myceliogenic or may be carpogenic (spore-producing apothecia) 
infections result from airborne spores produced by apothecia at the soil surface. Fungicides have a limited time period in which they are effective. Trichoderma spp. are important potential bioagents against these soilborne diseases. For the management of these diseases, farmers are using different fungicides but farmers are not getting satisfactory results. Therefore, farmers are applying talk based Trichoderma in soil with farm yard manure and other substrates for biological control of these soilborne diseases. For the use of these biocontrol agents in an integrated disease management programme, the bioagents must be compatible with the fungicides. Further, to minimise use of chemical fungicides, compatibility of Trichoderma with fungicides was studied.

\section{Materials and Methods}

Nine fungicides were evaluated against Trichoderma by Poisoned Food Technique.

\section{Compatibility test}

An in vitro experiment was conducted for the evaluation of compatibility of Trichoderma viride with nine fungicides by using poisoned food technique on potato dextrose agar medium. A weighed quantity of each fungicide was mixed in the PDA medium under aseptic conditions. For this PDA medium was amended with recommended doses of fungicides and poured in $90 \mathrm{~mm}$ culture plates. After solidification the agar medium in the culture plates the plates were inoculated with $5 \mathrm{~mm}$ culture disks of three days old culture of Trichoderma viride in the centre of petriplates and each treatment was replicated thrice. The plates without fungicide were served as control. The plates were incubated at $25 \pm 1^{\circ} \mathrm{C}$ in BOD. After 3 days of incubation the diameter of the mycelial growth of Trichoderma viride was measured and average mycelial growth was recorded. The average data from the replicated plates was taken and the result was expressed as percent inhibition of mycelial growth over the control. The percentage growth inhibition of Trichoderma expressed by using the following formula given by Vincent (1947):

Percentage growth inhibition $=\frac{C-T}{C} X 100$

Where

$\mathrm{I}=$ Percent Inhibition

$\mathrm{C}=$ Growth in control $(\mathrm{mm})$

$\mathrm{T}=$ Growth in treatment $(\mathrm{mm})$

\section{Results and Discussion}

Efficacy of nine systemic and non systemic fungicides was tested at different concentrations by Poisoned Food Technique (Table 1). The experimental findings (Table 2) indicated that all the fungicides significantly inhibited the mycelial growth of Trichoderma viride at all the concentrations tested, the results shows the per cent inhibition of mycelial growth of Trichoderma viride was recorded highest $78.52 \%$ Propiconazole followed by Azoxystrobin (76.66\%), Hexaconazole (68.88\%), Tebuconazole (68.52\%), Carbendazim (64.44\%), Thiophanate Methyl (54.44\%) and Iprodione $(42.58 \%)$ respectively at $25 \mathrm{ppm}$ concentration. Least mycelial growth inhibition percent of Trichoderma viride $17.03 \%$ was recorded with treatment Mancozeb followed by $42.58 \%$ with the treatment Captan at $50 \mathrm{ppm}$ concentration. In case of $50 \mathrm{ppm}$ concentration of fungicides maximum mycelial growth inhibition 89.63 was recorded by Propiconazole followed by Tebuconazole $\quad(88.88 \%), \quad$ Hexaconazole (84.44\%), Azoxystrobin (77.77\%), Carbendazim (76.66\%), Thiophanate Methyl $(74.44 \%)$ and Captan $(71.47 \%)$. While least inhibition of mycelial growth of $T$. viride $46.30 \%$ was recorded with Mancozeb at 100 ppm concentration followed by $57.77 \%$ with Iprodione at $50 \mathrm{ppm}$ concentration. The 
fungicides viz., Azoxystrobin, Tebuconazole, Propiconazole, Hexaconazole and Carbendazim at $100 \mathrm{ppm}$ concentration completely inhibited the growth of Trichoderma viride, showing no compatibility with Trichoderma viride, while Thiophanate Methyl at $100 \mathrm{ppm}$ concentration exhibited intermediate inhibitory effect and inhibited the radial growth of Trichoderma viride $89.25 \%$, followed by Captan (200 ppm) which shows mycelial growth inhibition $87.41 \%$ and Iprodione (100 ppm) 87.03\%.

Both fungicide were at par to each other and were less compatible with Trichoderma viride. Least mycelial growth inhibition was recorded with Mancozeb at $200 \mathrm{ppm}$ concentration $42.96 \%$, so mancozeb found to be most compatible within the fungicides evaluated.

Out of the nine systemic and non systemic fungicides tested, all the fungicides significantly inhibited the mycelial growth of Trichoderma viride at all the three concentrations, the results shows that highest mycelial growth inhibition recorded with the treatment $\mathrm{T}_{5}$ (Propiconazole) followed by the treatments Tebuconazole, Azoxystrobin, Hexaconazole, Carbendazim, Thiophanate methyl and Iprodione at $25 \mathrm{ppm}$ concentration indicates their incompatibility with the $T$. viride. Least mycelial growth inhibition of
Trichoderma viride was recorded with Carbendazim followed by Captan at $50 \mathrm{ppm}$ concentration which shows that these two fungicides were compatible with the Trichoderma viride. In case of $50 \mathrm{ppm}$ concentration of fungicides, highest mycelial growth inhibition was recorded with Propiconazole followed by Tebuconazole, Hexaconazole, Azoxystrobin, Carbendazim, Thiophanate methyl and Captan, it shows that these fungicides are incompatible with $T$. viride.

While least inhibition of mycelial growth of $T$. viride was recorded with Mancozeb at 100 ppm concentration followed by Iprodione at $50 \mathrm{ppm}$ concentration so these fungicides are compatible with the $T$. viride. The fungicides Azoxystrobin, Tebuconazole, Propiconazole, Hexaconazole and Carbendazim at $100 \mathrm{ppm}$ concentration completely inhibited the growth of Trichoderma viride and showing no compatibility with Trichoderma viride, while Thiophanate Methyl at $100 \mathrm{ppm}$ concentration exhibited intermediate inhibitory effect and inhibited the radial growth $89.25 \%$ followed by Captan $(200 \mathrm{ppm})$ mycelial growth inhibition $87.41 \% 144 \mathrm{hrs}$ and Iprodione (100 ppm) mycelial growth inhibition $87.03 \%$. Both fungicide were at par to each other and were less compatible with Trichoderma viride.

Table.1 List of fungicides

\begin{tabular}{|c|c|c|c|c|}
\hline S. No. & Name of the Fungicide & \multicolumn{3}{|c|}{ Concentrations } \\
\hline 1 & Azoxystrobin $23.1 \%$ W/W & $25 \mathrm{ppm}$ & $50 \mathrm{ppm}$ & 100 ppm \\
\hline 2 & Iprodione $500 \mathrm{SC}$ & 25 ppm & $50 \mathrm{ppm}$ & 100 ppm \\
\hline 3 & Tebuconazole 25\% EC & $25 \mathrm{ppm}$ & $50 \mathrm{ppm}$ & $100 \mathrm{ppm}$ \\
\hline 4 & Hexaconazole 5\% SC & $25 \mathrm{ppm}$ & $50 \mathrm{ppm}$ & $100 \mathrm{ppm}$ \\
\hline 5 & Propiconazole 25\% EC & $25 \mathrm{ppm}$ & $50 \mathrm{ppm}$ & $100 \mathrm{ppm}$ \\
\hline 6 & Carbendazim 50\% WP & $25 \mathrm{ppm}$ & $50 \mathrm{ppm}$ & $100 \mathrm{ppm}$ \\
\hline 7 & Thiophanate methyl 70\% WP & $25 \mathrm{ppm}$ & $50 \mathrm{ppm}$ & $100 \mathrm{ppm}$ \\
\hline 8 & Captan 50\% WP & $50 \mathrm{ppm}$ & $100 \mathrm{ppm}$ & $200 \mathrm{ppm}$ \\
\hline 9 & Mancozeb 75\% WP & $50 \mathrm{ppm}$ & $100 \mathrm{ppm}$ & 200 ppm \\
\hline
\end{tabular}


Table.2 Compatibility of Trichoderma harzianum with different fungicides

\begin{tabular}{|c|c|c|c|c|c|c|c|c|c|c|c|c|c|c|c|c|c|c|}
\hline Conc. & \multicolumn{6}{|c|}{25 ppm } & \multicolumn{6}{|c|}{50 ppm } & \multicolumn{6}{|c|}{100 ppm } \\
\hline Time & \multicolumn{2}{|c|}{48 hours } & \multicolumn{2}{|c|}{96 hours } & \multicolumn{2}{|c|}{144 hours } & \multicolumn{2}{|c|}{48 hours } & \multicolumn{2}{|c|}{96 hours } & \multicolumn{2}{|c|}{144 hours } & \multicolumn{2}{|c|}{48 hours } & \multicolumn{2}{|c|}{96 hours } & \multicolumn{2}{|c|}{144 hours } \\
\hline $\begin{array}{c}\text { Treatment } \\
\downarrow\end{array}$ & $\begin{array}{c}\text { Avg } \\
\text { radial } \\
\text { growth }\end{array}$ & $\begin{array}{c}\% \\
\text { inhibi } \\
\text { tion }\end{array}$ & $\begin{array}{l}\text { Avg } \\
\text { radial } \\
\text { growth }\end{array}$ & $\begin{array}{c}\% \\
\text { inhibi } \\
\text { Tion }\end{array}$ & $\begin{array}{c}\text { Avg } \\
\text { radial } \\
\text { growth }\end{array}$ & $\begin{array}{c}\% \\
\text { inhibi } \\
\text { tion }\end{array}$ & $\begin{array}{c}\text { Avg } \\
\text { radial } \\
\text { growth }\end{array}$ & $\begin{array}{c}\% \\
\text { inhibi } \\
\text { tion }\end{array}$ & $\begin{array}{c}\text { Avg } \\
\text { radial } \\
\text { growth }\end{array}$ & $\begin{array}{c}\% \\
\text { inhibi } \\
\text { Tion }\end{array}$ & $\begin{array}{c}\text { Avg } \\
\text { radial } \\
\text { growth }\end{array}$ & $\begin{array}{c}\% \\
\text { inhibi } \\
\text { tion }\end{array}$ & $\begin{array}{c}\text { Avg } \\
\text { radial } \\
\text { growth }\end{array}$ & $\begin{array}{c}\% \\
\text { inhibi } \\
\text { tion }\end{array}$ & $\begin{array}{c}\text { Avg } \\
\text { radial } \\
\text { growth }\end{array}$ & $\begin{array}{c}\% \\
\text { inhibi } \\
\text { tion }\end{array}$ & $\begin{array}{c}\text { Avg } \\
\text { radial } \\
\text { growth }\end{array}$ & $\begin{array}{c}\% \\
\text { inhibi } \\
\text { tion }\end{array}$ \\
\hline T1 & 12.00 & 62.88 & 20.00 & 67.38 & 28.00 & 68.88 & 5.00 & 85.71 & 14.00 & 77.29 & 20.00 & 77.77 & 0.00 & 100 & 0.00 & 100 & 0.00 & 100 \\
\hline $\mathbf{T} 2$ & 28.33 & 12.37 & 39.00 & 36.4 & 51.67 & 42.58 & 20.00 & 42.85 & 30.00 & 51.35 & 38.00 & 57.77 & 6.00 & 82.17 & 9.00 & 85.32 & 11.67 & 87.03 \\
\hline T3 & 8.67 & 73.18 & 14.00 & 77.17 & 21.00 & 76.66 & 0.00 & 100 & 7.00 & 88.64 & 10.00 & 88.88 & 0.00 & 100 & 0.00 & 100 & 0.00 & 100 \\
\hline T4 & 12.33 & 61.86 & 20.67 & 66.29 & 28.33 & 68.52 & 4.67 & 86.65 & 8.00 & 87.02 & 14.00 & 84.44 & 0.00 & 100 & 0.00 & 100 & 0.00 & 100 \\
\hline T5 & 4.33 & 86.6 & 11.00 & 82.06 & 19.33 & 78.52 & 0.00 & 100 & 5.67 & 90.8 & 9.33 & 89.63 & 0.00 & 100 & 0.00 & 100 & 0.00 & 100 \\
\hline T6 & 14.00 & 56.69 & 21.00 & 65.75 & 32.00 & 64.44 & 7.33 & 79.05 & 10.67 & 82.69 & 21.00 & 76.66 & 0.00 & 100 & 0.00 & 100 & 0.00 & 100 \\
\hline \multirow[t]{2}{*}{ T7 } & 18.67 & 42.25 & 26.00 & 57.6 & 41.00 & 54.44 & 8.33 & 76.2 & 13.67 & 77.83 & 23.00 & 74.44 & 5.67 & 83.16 & 7.00 & 88.58 & 9.67 & 89.25 \\
\hline & \multicolumn{6}{|c|}{50 ppm } & \multicolumn{6}{|c|}{100 ppm } & \multicolumn{6}{|c|}{200 ppm } \\
\hline T8 & 20.33 & 37.11 & 32.33 & 47.28 & 51.67 & 42.58 & 12.33 & 64.77 & 15.67 & 74.59 & 25.67 & 71.47 & 8.33 & 75.25 & 10.67 & 82.6 & 11.33 & 87.41 \\
\hline T9 & 30.33 & 6.18 & 54.67 & 10.85 & 74.67 & 17.03 & 22.67 & 35.22 & 31.67 & 48.64 & 48.33 & 46.30 & 15.50 & 53.96 & 29.67 & 51.62 & 51.33 & 42.96 \\
\hline Control & 32.33 & 0 & 61.33 & 0 & 90.00 & 0 & 35.00 & 0 & 61.67 & 0 & 90.00 & 0 & 33.67 & 0 & 61.33 & 0 & 90.00 & 0 \\
\hline C.D.0.05 & \multicolumn{2}{|c|}{1.172} & \multicolumn{2}{|c|}{1.686} & \multicolumn{2}{|c|}{1.566} & \multicolumn{2}{|c|}{1.291} & \multicolumn{2}{|c|}{1.502} & \multicolumn{2}{|c|}{1.520} & \multicolumn{2}{|c|}{1.129} & \multicolumn{2}{|c|}{1.039} & \multicolumn{2}{|c|}{1.253} \\
\hline S.E.(m) & \multicolumn{2}{|c|}{0.394} & \multicolumn{2}{|c|}{0.568} & \multicolumn{2}{|c|}{0.527} & \multicolumn{2}{|c|}{0.435} & \multicolumn{2}{|c|}{0.506} & \multicolumn{2}{|c|}{0.510} & \multicolumn{2}{|c|}{0.380} & 0.3 & & & \\
\hline
\end{tabular}


Least mycelial growth inhibition was recorded with Mancozeb at $200 \mathrm{ppm}$ was $42.96 \%$ and was most compatible within the fungicides evaluated. Similar work has been carried out by Ranganathswamy et al., (2012) evaluated eighteen fungicides for their compatibility to Trichoderma harzianum and Trichoderma virens in vitro, and observed that carbedazim, benomyl, carboxin, propiconazole, chlorothalonil, hexaconazole, tricyclazole and tridemorph were incompatible with Trichoderma sp. showing 100 per cent inhibition of radial growth. While dinocap, copper oxychloride, fosetylAl, captan, thiram and metalaxyl were found to be least compatible showing more than 70 per cent inhibition of radial growth. Bordeaux mixture, azoxystrobin and mancozeb were moderately compatible, only wettable sulphur was found to be highly compatible with Trichoderma isolates. Madhavi et al., (2011) observed that Trichoderma viride was highly compatible with mancozeb, on the other hand its mycelial growth was inhibited in the presence of captan and captan+ hexaconazole. Trichoderma viride was found totally incompatible with the systemic fungicide carbendazim which shows no mycelial growth. Nandeesha et al., (2013) studied the in vitro efficacy of four systemic fungicide carbendazim, propiconazole and hexaconazole and tebuconazole and two non systemic fungicides viz. mancozeb, and captan. Among all fungicides mancozeb was found highly compatible with Trichoderma viride. Saravanan et al., (2013) found that carbendazim was highly incompatible with $T$. viride at all concentrations tested as it completely inhibited the mycelial growth and to some extent mancozeb can be recommended in combination with $T$. viride in integrated pest and disease management programme.

In conclusion, in the present investigations experimental findings shows that
Azoxystrobin, Tebuconazole, Propiconazole, Hexaconazole and Carbendazim are not compatible with Trichoderma viride so these fungicides cannot be applied with Trichoderma viride for integrated management of Sclerotinia stem rot of lentil while, Mancozeb was found to be most compatible with Trichoderma viride so can be applied for the integrated management of Sclerotinia stem rot of lentil and other crops.

\section{References}

Bolland G and Hall R 1994. Index of plant hosts to Sclerotinia sclerotiorum. Canadian Journal of Plant Pathology 16: 93-108.

Gugel, R. K. and Morrall, R. A. A. (1986). Inoculum-disease relationships in sclerotinia stem rot of rapeseed in Saskatchewan. Can. J. Plant Pathol. 8: 89-96.

Madhavi, G.B., Bhattiprolu, S.L., and Reddy, V.B. (2011) Compatibility of bio control agent Trichoderma viride with various pesticides. Journal of Horticultural Sciences.6(1): 71-73.

Nandeesha, B.S., Kumar, M.R., and Reddy, N.P. (2013) Evaluation of different fungicides and their compatiblility with potential Trichoderma spp. for the management of Aspergillus niger, Incitant of collar rot of groundnut. Asian Journal of Biological and Life Sciences.

Purdy, L.H. (1979). Sclerotinia sclerotiorum. History disease and Symptomology, host range, geographic distribution, and impact. Phytopathol., 69, 875-880.

Rangnathswamy, M., Patibanda, A.K., Chandrasekhar, G.S., Sandeep, D., Mallesh, S.B., and Kumar, H.B.H. (2012). Compatibility of Trichoderma isolates with selected fungicides in vitro. International Journal of Plant Protection. 5(1): 12-15. 
Saravanan, L., Kalidas, P., Phanikumar, T., Deepthi, P., Babu, K.R. (2013) In vitro compatibility of Trichoderma viride with Agrochemicals. Ann. Pl. Protec.
Sci. 22 (1): 190-239.

Vincent, J.M., (1947). Distortion of fungal hyphae in the presence of certain inhibitors. Nature, 150, pp. 850.

\section{How to cite this article:}

Shashank Mishra, Prashant Mishra, Ramji Singh, Gopal Singh and Sachan, S.K. 2019.

Compatibility of Different Systemic and Non Systemic Fungicides with Trichoderma viride. Int.J.Curr.Microbiol.App.Sci. 8(01): 1005-1010. doi: https://doi.org/10.20546/ijcmas.2019.801.109 